\title{
A case of cerebral venous thrombosis accompanying with intracranial hypotension: Headache that changing character
}

\section{Intrakranyal hipotansiyon ile birliktelik gösteren serebral venöz tromboz olgusu: Karakter değiş̧tiven baş ağrısı}

\author{
Sibel GÜLER, Çiğdem DENiz, Ufuk UTKU, Sezgin KEHAYA
}

\begin{abstract}
Summary
Spontaneous intracranial hypotension was first described by Schalternbarn. Severe complications like cerebral venous thrombosis and subdural hemorrhage are seldomly seen. A 40-year-old man was examined for weakness of right arm started 9 months earlier and aggravated in last 3 months. He was undergo a lumbar punction because of a demyelinating plaque at $\mathrm{C} 2$ level in MRI. After 10 days of lumbar punction he experienced a generalised tonic clonic seizure. At cranial MRI and venography thrombosed superior sagittal and right transverse sinus and image of pachymeningitis, caused by intracranial hypotension were observed. Coincidence of these two situations together was seldomly found at literature. Thrombosis can both effect the sinuses and cortical veins. Spontaneous intracranial hypotension is a risk factor for CVT, but at only $2 \%$ CVT is seen as a complication. We think that our case can add addition to literature by having this coincidence.
\end{abstract}

Key words: Cerebral venous thrombosis; intracranial hypotension; prognosis; treatment.

\begin{abstract}
Özet
Spontan intrakraniyal hipotansiyon literatürde ilk kez Schaltenbran tarafindan tanımlanmıştı. Subdural hemoraji ve serebral venöz tromboz gibi ciddi komplikasyonlar nadir olarak gözlenmektedir. Kırk yaşında erkek hasta yaklaşık dokuz ay evvel sağ kolda belirgin olan ve son ǚç aydır giderek artan gücsüzlük yakınmalart ile değerlendirildi. Servikal MRG'de C2 düzeyinde şüpheli demiyelinizan plak görüllmesi üzerine lomber ponksiyon uygulandı̆̆ı belirtildi. Lomber ponksiyon incelemesinden sonra ortostatik baş ağrısı gelişen olgunun 10. günde ise jeneralize tonik klonik epileptik nöbet kliniğ i geliştĭgi izlendi. Kraniyal MR venografide sağ transvers sinüs ve süperior sagittal sinüste tromboz ve intrakraniyal bipotansiyona bağlt pakimenenjit bulgular birarada gözlendi. Literatürde bu iki olayın birlikteliğine çok nadir olarak rastlanmaktadır. Tromboz hem venöz sinüsleri hem de kortikal venleri etkileyebilir. Spontan intrakraniyal bipotansiyon serebral venöz tromboz için risk faktörüdür, fakat olgularn sadece \%2'sinde bir komplikasyon olarak gelişebilir. Olgumuzun da bu nadir birliktelik dolayısıyla literatüre katkı sağladığı düşünülmektedir.
\end{abstract}

Anahtar sözcükler: Serebral venöz tromboz; intrakraniyal hipotansiyon; prognoz; tedavi.

\section{Introduction}

Spontaneous intracranial hypotension $(\mathrm{SIH})$ was first described by Schaltenbran. ${ }^{[1]}$ At this syndrome the pressure of serebrospinal flud is measured 70 $\mathrm{mm} \mathrm{H}_{2} \mathrm{O}$ or less at lateral position and no trauma history is optained. Severe complications like cerebral venous thrombosis (CVT) and subdural hemorrhage are seldomly seen. Thrombosis, thrombophilia and treatment with steroids was proposed as risk factors for his coincidence. ${ }^{[2,3]}$ We discuss the rare coin- 
cidence of SIH with radiologic and clinical findings and CVT with literature findings.

\section{Case Report}

A 40-year-old man complained of weakness at right side of his body 9 months ago that progressed at last 3 months. A demyelinating plaque at $\mathrm{C} 2$ level was found in cervical magnetic resonance imaging (MRI) study done in other medical facility. He was undergo a lumber punction for oligoclonal bands and IGG index in CSF. After then he was felt a headache, starting from neck and becoming worse standing up. After 10 days of lumbar punction (LP) he experienced a generalize tonic clonic seizure starting with eye and head bending. At neurological examination, only the right upper extremity muscle strenght was found $-5 / 5$, otherwise normal.

\section{Diagnostic procedures}

Full blood count, biochemistry and erythrocyte sedimentation rate was found normal. Serum hepatitis markers, Venereal Disease Research Laborator, Brucella agglutination test, HIV, Varicella zoster, toxoplasma and Lyme disease anticors view all negative. ANA, anti-DNA, angiotensin converting enzyme, anticardiolipin anticors, SS-A and SS-A autoantibody were negative. Rheumatoid factor, Protein $\mathrm{C}$ and $S$, antithrombin III were at normal range.

At cranial MRI with contrast material, pachymeningeal thickening and contrast enhancement due to intracranial hypotension, caused by stasis at leptomeningeal spaces was observed (Fig. 1a). Diffuse cerebral edema and enlargement of cortical viens at right hemisphere were observed, too. At cranial MR venography, right transverse sinus, sigmoid sinus and superior sagittal sinus were thrombosed (Fig. $1 b, c)$. EEG showed highly active paroxysmal discharge at right frontotemporal region.

With clinical and radiologic findings, the case was diagnosed as SIH and CVT. For SIH, he was treated with cafein, teofilin, hydratation, and levetirasetam $1000 \mathrm{mg} /$ day to control epileptic activity. Headache and epileptic seizures were stoped with the treatment. For CVT, treatment with warfarin sodium was done controlling INR between 2-3. At MR venography done 35 days later, superior sagittal sinus was recanalized and right transverse sinus was recanalized too, but thrombus in the lumen persisted. The lesion at cervical MRI was regressed, therefore it was thought to be due to nonspecific myelopathy. The findings of cerebral edema and $\mathrm{SIH}$ were regressed too. Neurological examination findings after 1 month were normal.

\section{Discussion}

The co-presentation of these two situation together is seldomly seen in literature. Untill 2004 co-presentation of SIH and CVT was not reported. But at 1980's CVT after iatrogenic CSF leakage was presented. This co-presentation sould not be taken as
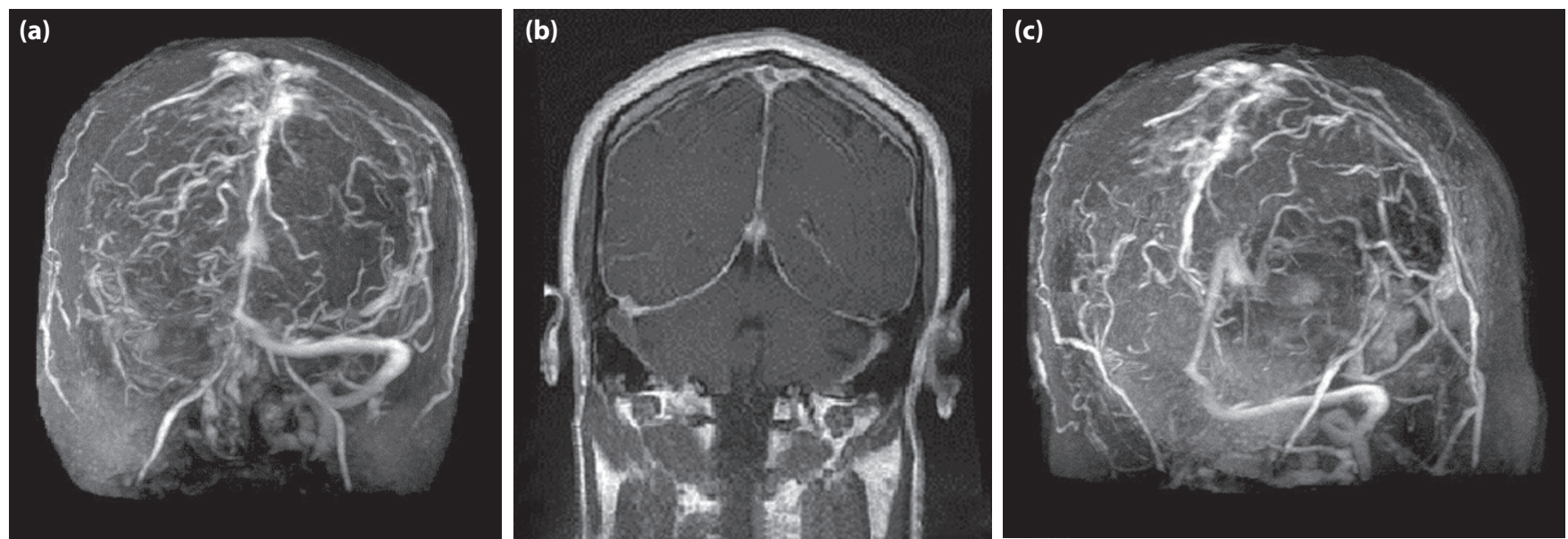

Figure 1. (a) At cranial MRI with contrast material, pachymeningeal thickening and contrast enhancement due to intracranial hypotension, caused by stasis at leptomeningeal spaces was observed. $(\mathbf{b}, \mathbf{c})$ At cranial MR venography, right transverse sinus, sigmoid sinus and superior sagittal sinus were thrombosed. 
coincidence. SIH should be seen as risk factor for CVT ${ }^{[4]}$ In literature a case with CVT caused by $\mathrm{SIH}$ was presented to have prothrombin gene mutation and protein $\mathrm{C}$ resistance as risk factor. In our case no additional risk factor was found.

At SIH, the volume of CSF is reduced that can cause increase in volume of venous system and stasis caused by reduced outflow. Thrombosis can influence cortical veins and dural sinuses causing CVT. The co-presentation of SIH and CVT can be explained by some mechanisms. First is Monroe-Kellie hypothesis. This propose that: reduction in CSF volume causes increase in intracranial blood flow, intracranial spasm and occurance of CVT by compansatory mechanisms. ${ }^{[5,6]}$ With transcranial Doppler sonography reduction of blood flow in serebral sinuses up to $50 \%$ was observed after LP. ${ }^{[7]}$ Second, at $\mathrm{SIH}$ brain go down according to gravity and this course traction in serebral veins and sinuses. The traction may lead to mechanical distorsion of venous stuctures. Third, reduction of CSF volume can reduce absorbtion of CSF to serebral venous sinuses causing increased viscosity. ${ }^{[8]}$

CVT is a rare complication of SIH and seen in 1 in 5 million population. ${ }^{[9]}$ Schievink and Maya observed $141 \mathrm{SIH}$ cases and CVT was only seen in $3(2.1 \%)$ as a complication. ${ }^{[10]}$ Haritanti and his colleague ${ }^{[11]}$ had reported $1 \mathrm{SIH}$ in 6 CVT (17\%), Li and colleague $^{[12]} 1$ in $11(9 \%)$, Berroir and colleague ${ }^{[2]}$ two in $30(7 \%)$ CVT as a risk factor.

SIH and CVT are rare causes of headache. Orthostatic headache is an important finding in CVT related to SIH. ${ }^{[2]}$ It is reported in many of reports as ours $^{[3,13]}$ In SIH, headache has orthostatic character, getting worse standing up, and relieved in supine position. ${ }^{[14]}$ In CVT headache is continuous and has no orthostatic relation. In our patient headache was firstly orthostatic than become irrelevant from position. We think this is caused of CVT after SIH. At this co-presentation not only headache but also seizures, cerebral venous infarcts and dural arteriovenous fistula can be presented. In our case only epileptic seizure was observed.

At cranial MRI, CVT findings can be easily mistaken in SIH because florid contrast enhancement at perivascular and leptomeningeal spaces. ${ }^{[15]}$ At headache, changing character, isointens and hyperintense thrombosis findings should be searched in MRI. At our case CVT and SIH's radiologic findings are seen together. Cerebral and cortical vasogenic edema showing venous hypertension indirectly should not be taken as a finding of SIH at MRI. When these findings are observed MRI venography should be done. In our case the findings of SIH and CVT at MRI are seen together, that is not shown in other literature.

There are some disagreements in treatment of SIH complicated with CVT. Conservative approach for SIH and anticoagulation for CVT is mostly advised. If the symptoms of SIH persist although conservative treatment is done epidural blood cloth patching could be considered. The mortality of CVT is 5\% but with SIH, it can be increased therefore firstly SIH should be threatened. CVT is not reported in any SIH case who's clinical symptoms are vanished. In our case the patient perceived anticoagulant therapy after SIH symptoms were vanished.

We tried to confirm the relationship between SIH and CVT. A headache having orthostatic character and then becoming resistant to medication and irrelevant with posture should be searched for CVT. MRI venography should be done to visualise thrombosis. SIH is a risk factor for CVT but only at $2 \%$ is seen as a complication. ${ }^{[10]}$ We think that our case can add additional information to literature having this two situations together.

\section{Conflict-of-interest issues regarding the authorship or article: None declared.}

\section{Peer-review: Externally peer-reviewed.}

\section{References}

1. Schaltenbrand G. Neuere anschauungen zur pathophysiologie der liquorzirkulation. Zentralbl Neurochir 1938;3:290300.

2. Berroir S, Grabli D, Héran F, Bakouche $P$, Bousser MG. Cerebral sinus venous thrombosis in two patients with spontaneous intracranial hypotension. Cerebrovasc Dis 2004;17(1):9-12.

3. Kataoka $H$, Tanizawa $E$, Ueno S. Spontaneous intracranial hypotension is associated with a risk of venous sinus thrombosis and subdural hematoma. Cerebrovasc Dis 2007;23(4):315-7. 
4. de Freitas GR, Bogousslavsky J. Risk factors of cerebral vein and sinus thrombosis. Front Neurol Neurosci 2008;23:2354.

5. Kellie G. An account with some reflections on the pathology of the brain. Edinburgh Med Chir Soc Trans 1824;1:84-169.

6. Monroe J. Observations on the structures and functions of the nervous system. Edinburgh: Creech \& Johnson; 1783.

7. Canhão P, Batista P, Falcão F. Lumbar puncture and dural sinus thrombosis--a causal or casual association? Cerebrovasc Dis 2005;19(1):53-6.

8. Park JH, Yoon SH. New concept of cerebrospinal fluid dynamics in cerebral venous sinus thrombosis. Med Hypotheses 2008;70(1):143-7.

9. Stam J. Thrombosis of the cerebral veins and sinuses. $\mathrm{N}$ Engl J Med 2005;352(17):1791-8.

10. Schievink WI, Maya MM. Cerebral venous thrombosis in spontaneous intracranial hypotension. Headache
2008;48(10):1511-9.

11. Haritanti A, Karacostas D, Drevelengas A, Kanellopoulos V, Paraskevopoulou E, Lefkopoulos A, et al. Spontaneous intracranial hypotension: clinical and neuroimaging findings in six cases with literature review. Eur J Radiol 2009;69(2):2539.

12. Li JY, Lai PH. Spontaneous intracranial hypotension: Clinical and neuroimaging spectrum. Neurology 2005;64:351.

13. Savoiardo M, Armenise $S$, Spagnolo P, De Simone T, Mandelli $\mathrm{ML}$, Marcone A, et al. Dural sinus thrombosis in spontaneous intracranial hypotension: Hypotheses on possible mechanisms. J Neurol 2006;253(9):1197-202.

14. Ferrante E, Savino A, Sances G, Nappi G. Spontaneous intracranial hypotension syndrome: report of twelve cases. Headache 2004;44(6):615-22.

15. Virapongse C, Cazenave C, Quisling R, Sarwar M, Hunter S. The empty delta sign: frequency and significance in 76 cases of dural sinus thrombosis. Radiology 1987;162(3):779-85. 